\title{
Identitas Kristus versus Krisis Identitas
}

\section{Virginia Gunawan'}

\section{M}

asa remaja adalah masa yang menentukan masa depan. Siapa mereka dan a pa yang akan mereka lakukan sekarang di masa yang akan datang mulai dikerjakan pada masa remaja. Tetapi kesempatan dan peluang berkembang ini juga dibayang-bayangi dengan ancaman, karena di periode inilah mereka menerima berbagai tawaran sekaligus memberi kesempatan mereka untuk mengambil keputusan. Oleh sebab itu masa remaja juga menjadi masa yang rentan. Apabila mereka tidak memiliki dasar kedewasaan yang cukup, maka mereka bisa jatuh ke dalam keputusan yang membawa berbagai kesulitan. Tawaran dan peluang yang ada di sekitar mereka sering kali menjebak mereka dalam krisis identitas, yang fenomenanya misalkan kecanduan pornografi, narkoba, dan lainnya.

Son Kuswadi, ahli informatika dari ITS Surabaya dalam Talk Show "Internet Sehat" di Universitas Surabaya (Ubaya) tanggal 29 Maret 2009, menyatakan laporan NRC (The National Research Council) tahun 2002 bahwa industri pornografi melaporkan 20-30 persen remaja di dunia yang berusia 8-17 tahun mengakses situs porno, secara rutin. Itu data tahun 2002 dan kemungkinan besar sekarang ini jumlahnya semakin meningkat. Son Kuswadi, yang juga adalah staf khusus Menkominfo, melanjutkan bahwa 90 persen remaja telah mengakses situs porno. ${ }^{2}$

Di Indonesia, kajian yang pernah dilakukan KPAI menemukan terjadi peningkatan perilaku seks remaja diantaranya adalah karena kemudahan mengakses pornografi. ${ }^{3}$ Dalam Survei Kesehatan Re-

1. Virginia Gunawan, S.E, M.A, M.Th., CGA adalah seorang konselor dan mentor spesialis anak muda. Tahun 2016 memperoleh sertifikasi grafologi dalam membaca karakter anak muda dari tulisan mereka. Saat ini beliau memimpin Yayasan Generasi Puzzle Cemerlang (Puzzle of Life) yang bergerak di bidang Training and Counseling Center.

2. Alex Nanlohy, "Remaja Kristen di Tengah Kungkungan Krisis Zaman," https://www. kompasiana. com/alexnanlohy/ 55202b75a333110744b65bdc/remaja-kristen-di-tengah-kungkungan-krisis-zaman (diakses 31 Oktober 2015).

3. Misbahol Munir, “Tiap Tahun, Remaja Seks Pra Nikah Meningkat,” https://news. okezone. com/read/2010/12/04/338/ 400182/tiap-hun-remaja-seks-pra-nikah-meningkat (diakses 15 November 2011). Penelitian Komnas Perlindungan Anak (KPAI) di 33 Provinsi pada bulan Januari-Juni 2008 menyimpulkan kecenderungan peningkan perilaku seksual di mana 62,7\% remaja sudah melakukan perilaku seksual pranikah 97\% remaja SMP dan SMA pernah menonton film porno. Kedua, 93,7\% remaja SMP dan SMA pernah ciuman, genit stimulation (meraba alat kelamin) dan oral seks. Ketiga, 62,7\% remaja SMP tidak perawan, dan yang terakhir, $21,2 \%$ remaja mengaku pernah aborsi. 
produksi Remaja 2012 mengungkap beberapa perilaku berpacaran remaja yang belum menikah, antara lain, sebanyak 29,5 persen remaja pria dan 6,2 persen remaja wanita pernah meraba atau merangsang pasangannya, sebanyak 48,1 persen remaja laki-laki dan 29,3 persen remaja wanita pernah berciuman bibir, sebanyak 79,6 persen remaja pria dan 71,6 persen remaja wanita pernah berpegangan tangan dengan pasangannya.

Belum lagi narkoba, Drs. Ahmad Alamsyah, Kepala Bidang Pencegahan BNN (Badan Narkotika Nasional) provinsi Lampung menuturkan, kasus penggunaan narkoba di Indonesia sangat miris, dari 3,3 juta orang pengguna narkoba pada tahun 2008 lalu, sebanyak 93 persen pada kelompok usia produktif, 15-34 tahun. ${ }^{4}$ Di tahun 2014, terjadi peningkatan, dan 80 persen diantaranya berada pada usia produktif yaitu 16 sampai 30 tahun. $^{5}$

Data lain terkait dengan internet menunjukkan penelitian yang diadakan oleh Kementerian Informasi dan Informatika (Kominfo), UNICEF dan Harvard University ini mengambil sampel 400 remaja berumur 10-19 tahun yang tersebar di 11 provinsi Indonesia di 2014 . Hasilnya ternyata sungguh mengejutkan, hampir 80 persen remaja di Indonesia kecanduan internet. ${ }^{6}$

Dalam hal ini remaja Kristen pun mengalami tantangan yang sama dan ba- nyak dari mereka pun jatuh dalam kegagalan. Mereka yang sudah mendapatkan pembinaan-pembinaan sekalipun sering kali gagal dan mengalami fenomenafenomena seperti di atas. Menurut riset yang dilakukan Josh McDowell dan Bob Hostatler sebagaimana dicantumkan dalam McDowell ditemukan fakta perilaku seks remaja gereja usia 17-18 tahun sebagai berikut: ${ }^{7}$

- 95 persen berpacaran dengan bergandengan tangan.

- 86 persen berpacaran dengan melakukan pelukan.

- 74 persen berpacaran dengan melakukan french kissing (a kiss with contact between tongues - Concise Oxford English Dictionary).

- 55 persen berpacaran dengan meraba-raba buah dada.

- 44 persen berpacaran dengan meraba-raba alat kelamin.

- 27 persen berpacaran dengan melakukan hubungan seksual.

Jadi remaja Kristen pun sebenarnya mengalami pergolakan tidak berbeda jauh dengan remaja pada umumnya. Mereka pun tidak memiliki dasaryang kuat untuk mengidentifikasi dirinya sebagai remaja yang sudah memiliki identitas dalam Kristus.

Dalam penulisan ini, dilakukan survei kepada sekitar 34 remaja pemuda dari berbagai gereja dengan mengunakan sur-

4. Soni, "93 Persen Pengguna Narkoba Masuk Usia Produktif," http://lampung. tribunnews. com/2012/05/05/93-persenpengguna-narkoba-masuk-usia-produktif (diakses 15 November 2011).

5. http://repository. maranatha. edu/8077/3/0430108_Chapter1.pdf (diakses 15 November 2015)

6. "80 Persen Remaja Indonesia Kecanduan Internet," http://www. wowkeren.com/berita/tampil/00046680. html (diakses 15 November 2011)

7. Josh McDowell dan Bob Hostetler, Right from Wrong (Nashville: Word Publishing, 1995), 263. 
vei Identitiy Crisis Test yang terdiri atas 31 pertanyaan dan hasilnya adalah hanya 2 remaja yang memiliki identitas dalam Kristus yang kokoh, itu pun mereka masuk dalam kategori usia remaja akhir (1822 tahun). Sisanya memiliki cara pandang terhadap diri yang masih mudah digoyahkan dengan berbagai situasi yang mereka alami. Beberapa pernyataan yang banyak dijawab dengan identitas yang terdistorsi adalah: ${ }^{8}$

- Kalau saya merasa cukup percaya diri, maka saya akan menemukan kebahagiaan sejati.

- Saya menemukan identitas diri saya dalam relasi dengan keluarga (orang tua atau saudara kandung).

- Saat saya melihat diri saya, muncul pertanyaan apakah mungkin Tuhan dapat menggunakan saya untuk pekerjaan-Nya.

- Saya hanya manusia yang tidak mampu menjaga diri dari kejatuhan dosa yang sama berkali-kali.

- Ada orang atau kondisi yang menyebabkan saya tidak menjadi seperti apa yang Tuhan mau.

- Saya menemukan identitas utama dalam pekerjaan atau pelayanan.

- Saya terkadang ingin menyenangkan orang lain, meski saya tahu yang saya lakukan salah.

Akibatnya identitas remaja ini banyak dipengaruhi dengan bagaimana cara mereka memandang dirinya yang rendah. Padahal identitas yang kokoh dan sehat
Bagaimana sebagai pembimbing/pembina menolong remaja menemukan identitas di dalam Kristus tidak cukup hanya melalui pemahaman teologia, tetapi kita juga perlu memahami siapakah kaum muda dari sudut pandang yang lain seperti psikologi remaja dan budaya yang sekarang sangat memengaruhidunia anak muda.

sangat penting, seperti penelitian Lee Vukich dan Steve Vandegriff memberikan empat alasan pentingnya identitas: ${ }^{9}$

1. Orang harus mengembangkan identitas sehingga ia dapat memandu pembangunan masa depan.

2. Orang akan hadapi banyak pilihan keputusan, dan mereka harus memilih.

3. Orang tanpa identitas memilih karena tekanan.

4. Identitas diri penting dalam menemukan panggilan hidup yang memuaskan.

Bagaimana sebagai pembimbing/ pembina menolong remaja menemukan identitas di dalam Kristus tidak cukup hanya melalui pemahaman teologia, tetapi kita juga perlu memahami siapakah kaum

8. "Identity Crisis Test," http://www. wholeperson-counseling.org/ndoc/id-test.html (diakses 31 Oktober 2015).

9. Lee Vukich dan Steve Vandegriff, Timeless Youth Ministry: A Handbook for Successfully Reaching Today Youth (Chicago IL: Moody Publisher, 2002). 
muda dari sudut pandangyang lain seperti psikologi remaja dan budaya yang sekarang sangat memengaruhi dunia anak muda.

\section{Identitas dalam Psikologi}

\section{A. Erik Erikson}

Erikson adalah penulis paling berpengaruh tentang identitas, dan melalui tulisan dan penelitiannya identitas sekarang dilihat sebagai aspek penting dalam remaja. Erikson menyebut masa remaja sebagai fase identitas versus kebingungan identitas. Selama fase ini, remaja biasanya akan memutuskan siapa mereka, dan di mana mereka akan hidup atau tujuan hidup. ${ }^{10}$ Tahap remaja menjadi masa mencoba untuk menemukan identitas dengan harapan menemukan keunikan diri.

Erikson mengatakan bahwa identitas ini muncul dari dua sumber, yaitu pertama, penegasan atau penghapusan identitas pada masa kanak-kanak, dan kedua, kesediaan menerima standar tertentu. ${ }^{11}$ Penghapusan identitas masa kanak-kanak terjadi karena mereka ingin dianggap bisa dan mampu. Di masa inilah ketegangan sering terjadi dengan orang tua yang bingung dengan anaknya yang mulai remaja, karena sulit diatur dan dinasehati. Penerimaan standar tertentu yang dimaksud adalah persetujuan dari orang sekitar. Biasanya remaja akan menghargai pandangan rekan-rekan mereka lebih tua dari mereka. Identitas itu sendiri didefinisikan baik oleh positif dan negatif sebagai evaluasi atas apa yang terjadi dalam kehidupan seseorang, biasanya melewati ekspe- rimen perilaku. In i berarti bahwa individu akan memilih ingin menjadi seperti apa atau tidak seperti apa, dikonfirmasi oleh sekelilingnya atau lingkungan yang menjadi standar bagi dirinya.

Krisis identitas adalah sindrom masalah-masalah yang meliputi: terbaginya bagian diri, ketidakmampuan membina persahabatan yang akrab, kurang memahami pentingnya waktu, tidak bisa konsentrasi pada tugas yang memerlukan hal itu, dan menolak standar keluarga atau standar masyarakat.

Mereka yang tidak dapat menemukan identitas atau krisis identitas, mengalami kebingungan identitas hingga tahap mengisolasi diri. Kebingungan identitas berakibat pada ketidakmampuan untuk membangun keintiman, kurangnya konsentrasi pada tugas-tugas yang diberikan dan penolakan dari keluarga atau standar komunitas. Sebaliknya dengan penemuan identitas yang tepat akan membuat mereka memiliki prinsip, kebebasan untuk memutuskan bagaimana berperilaku, percaya rekan-rekan, orang dewasa yang berada di sekitar hidup mereka, dan memiliki keyakinan dalam pilihan mereka.

Erikson mengatakan bahwa orang harus mengalami keragu-raguan dan kebingungan tentang identitas mereka dalam rangka untuk mendapatkan kestabilan identitas. Terlalu banyak kebingungan dapat menyebabkan regresi ke periode perkembangan sebelumnya, menunda tanggung jawab menuju dewasa.

10. John W. Santrock, Essential of Life-Span Development (New York, NY: McGraw-Hill Education, 2007), 285.

11. Santrock, Essential of Life-Span Development, 285.

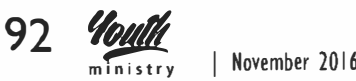




\section{B. James Marcia}

Marcia meneruskan apa yang ditulis Erikson. Teorinya disebut identitas struktur diri. ${ }^{12}$ Ia menjelaskan identitas itu sifatnya internal, merupakan organisasi yang dinamis yang dibangun sendiri dari dorongan internal, kemampuan, kepercayaan, dan pengalaman individu.

Identitas dalam seorang individu yang dinamis dan terus berubah, terus ditambahkan dan ada juga yang dibuang. Marcia tidak menempatkan pentingnya identitas, tetapi lebih pada proses pembentukan identitas. Marcia menempatkan fokus utama titik menemukan proses identitas dalam tahap remaja karena mereka memang mengalami perkembangan perilaku kognitif, perilaku psikososial, dan penerimaaan diri. Di saat remajalah pertama kalinya perkembangan fisik, keterampilan kognitif, dan harapan sosial, bergabung dengan pengalaman masa kecil mereka, membangun rancangan masa depan menuju dewasa. ${ }^{13}$ Marcia mengatakan bahwa krisis identitas dialami sepanjang hidup mereka dan hanya berkembang dengan baik, sehat apabila ia mampu mengambil perubahan dan bertindak fleksibel.

Marcia mengklasifikasi status ini atas dua dimensi yang ia dianggap penting: eksplorasi/krisis dan komitmen. Eksplorasi menjelaskan sejauh mana seseorang telah mengeksplorasi berbagai pilihan untuk karir atau nilai-nilai. Komitmen menjelaskan sejauh mana seseorang telah membuat keputusan tentang jalur identitas dan melakukan investasi pribadi dalam mencapai identitas itu. Dari dua dimensi ini, ada empat status identitas yang berbeda: difussion, foreclosure, moratorium, dan achievement.

Identitas difussion terjadi ketika seseorang tidak mengeksplorasi alternatif identitas lain dan belum membuat komitmen. Remaja ini tidak memikirkan masa depannya, menunggu segala sesuatu seakan hidup itu adalah takdir semata yang harus ia jalani.

Identitas foreclosure terjadi ketika seseorang membuat komitmen untuk identitas sebelum menjelajahi alternatif lain. Remaja ini mengikuti arus seperti pendapat orang tua, teman untuk ikut menjadi seseorang, meskipun ia sendiri mungkin tidak mengenal kemampuan dirinya atau terlalu berat untuknya mencoba alternatif yang tidak disarankan orang sekitarnya.

Identitas moratorium terjadi ketika seseorang belum berkomitmen untuk identitas dan masih terus bereksperimen dengan berbagai kemungkinan alternatif identitas. Remaja ini mulai gelisah karena menyadari ada berbagai kemungkinan alternatif identitas yang ia bisa pilih. Ia masih menjalani tahap coba-coba, namun ragu untuk sampai tahap keputusan akhir.

Identitas achievement terjadi ketika seseorang telah mengeksplorasi identitas alternatif dan telah membuat komitmen. Remaja ini menggunakan waktu yang ia

12. James E. Marcia, "Identity in Adolescent," dalam Handbook of Adolescent Psychology, ed. Joseph Adelson (New York: John Wiley \& Sons, 1980), 159.

13. Marcia, "Identity in Adolescent," 160. 
punya selama masa remaja untuk kenal diri, kembangkan diri sehingga pada waktu saatnya mengambil keputusan ingin menjadi apa, ia sudah tahu pasti apa yang ia mau dan ia yakini.

Marcia melakukan percobaan yang berkaitan status identitas dengan variabel lain yaitu informasi negatif. Hasil percobaan adalah untuk mengukur bagaimana masing-masing status identitas bereaksi. Peserta yang dalam status achievement hasilnya lebih baik daripada status lain selama tekanan pengujian, dan harga diri mereka tidak rentan atau berubah ketika diberi informasi negatif. Marcia juga menemukan individu dalam status itu lebih sadar keunikan mereka sendiri, kesamaan dengan orang lain, dan kekuatan dan kelemahan mereka sendiri.

Di sisi lain, orang-orang dengan proses identitasnya kurang berkembang menjadi bingung dengan keunikan mereka dan lebih mengandalkan sumber eksternal untuk mengevaluasi diri. Hal ini menyebabkan masalah ketika budaya membombardir orang dengan pesan tentang siapa mereka. Kesimpulan yang ditarik adalah bahwa identitas yang tidak sehat menghasilkan rendah diri dan individu yang rentan, mudah mengalah pada kebohongan yang diberitahu kepada mereka oleh orang-orang sekitar mereka.

Sebagai tambahan, krisis identitas tidak terbatas hanya untuk remaja. Mereka dapat berlangsung sepanjang hidup sese-

\section{Jadi masa remaja itu memang masa remaja alami krisis identitas yang semakin diperparah karena gempuran budaya yang berkembang pesat di masa ini.}

orang, biasanya ketika ada perubahan besar dalam kehidupan seseorang. Jika identitas tidak dibangun di atas kebenaran, maka mereka tidak menjalani hidup dengan mengembangkan potensi Allah bagi mereka secara maksimal. Mereka yang membangun identitas yang sehat akan bertumbuh dalam iman mereka.

Krisis ini menjadi semakin rentan karena gempuran budaya di masa kini. Identitas sangat dipengaruhi dengan kondisi budaya. Budaya yang sekarang ini berkembang di tengah anak muda menurut Mueler dalam buku artikelnya: ${ }^{14}$

1. Romantisme kedekatan dengan lawan jenis; saya bahagia kalau saya dicintai.

2. Akademis/prestasi; saya dipuji karena hebat.

3. Harta; saya berhasil karena kaya.

4. Kesenangan; saya bahagia karena nyaman, saya berkuasa.

5. Penerimaan orang lain; saya berharga karena punya banyakteman.

6. Tujuan yang mulia (bikin perbe-

14. Walt Mueller, "Identity, World and Word," https://cpyu. org/resource/identity-world-andword/2009/ (diakses 15 November 2011).

$94 \underset{\text { ministry }}{\text { Youlf }}$ November 2016 
daan); saya berhasil karena kehebatanku.

7. Religiositas dan moral; saya benar karena kesucianku.

Jadi masa remaja itu memang masa remajaalamikrisisidentitas yang semakin diperparah karena gempuran budaya yang berkembang pesat di masa ini. Oleh sebab itu penting sekali para pembina menolong mereka menghadapi situasi ini, dengan menguatkan mereka akan identitas dalam Kristus.

\section{Identitas dalam Kristus}

Istilah "identitas dalam Kristus" sebenarnya tidak dipakai dalam Alkitab, tetapi konsepnya diajarkan berulang kali, khususnya di dalam Alkitab Perjanjian Baru. Masalah identitas sangat penting sekali, sebab pada dasarnya hidup manusia dibentuk dari bagaimana ia menerima identitasnya, khususnya sangat krusial di masa remaja yang memang sedang membentuk identitas tersebut. Bagaimana seseorang bersikap, berespons, dan bereaksi terhadap lingkungan hidupnya adalah tergantung (sadar atau tidak sadar) pada persepsi terhadap dirinya sendiri.

Identitas dalam Kristus menjadi satu keharusan bagisetiap anak Tuhan karena jika seorang Kristen tidak memiliki perbedaan secara mendasar dengan orang yang bukan Kristen, atau jika cara mereka memandang diri mereka tidak ada bedanya dengan orang yang bukan Kristen, maka hidup orang Kristen akan menjadi hidup yang biasa saja dan hampir tidak ada bedanya dengan mereka yang bukan Kristen. Hidup yang demikian akan menghasilkan kekalahan yang berulang-ulang dalam menjalani hidup Kristennya. Musuh kita, si iblis, akan memanfaatkannya dengan membebani kita dengan rasa bersalah karena hidup Kristen kita hanya akan dikacaukan dengan tuntutan aturanaturan legalistik. Jika gagal keselamatan kita akan dipertanyakan dan akhirnya kita akan menerima keberadaan hidup rohani yang naik turun sebagai keadaan yang normal. Orang Kristen yang kalah akan mengakui keburukan dan kecenderungan mereka untuk berbuat dosa. Sekalipun telah berusaha melakukan yang lebih baik, namun hatinya tetap mengakui bahwa dia hanyalah seorang pendosa yang diselamatkan oleh anugerah dan tidak ada yang dapat dilakukan selain menunggu kedatangan Tuhan yang kedua kali. Atau banyak juga orang Kristen terus menerus mengalami krisis identitas dan selalu lupa siapa mereka di dalam Kristus. Akibatnya mereka menanyakan "Siapa saya?" dan dipengaruhi oleh budaya untuk bisa menjawab kegelisahan tersebut. ${ }^{15}$

Inilah yang menyebabkan banyak orang Kristen, khususnya remaja yang mengaku dirinya pengikut Kristus, namun hidupnya terjebak dengan fenomena dunia. Mengapa ini menjadi gambaran kebanyakan hidup remaja Kristen? Jawabannya adalah karena ketidaktahuan mereka akan identitas yang benar di

15. Mark Driscoll, Who Do You Think You Are?: Finding Your True Identity in Christ (Nashville, Tennessee: Thomas Nelson, 2013), 51. 
dalam Kristus. Karya penebusan Kristus yang mengubah para pendosa menjadi orang kudus merupakan karya terbesar yang Allah kerjakan di dunia ini. Perubahan yang terjadi di dalam diri manusia ini akan berpengaruh sejak kita menerima keselamatan. Sedangkan perubahan yang dilihat dari luar masih akan terus menerus berlangsung hingga akhir hidupnya, inilah yang disebut sebagai proses "pengudusan" (sanctification). Tetapi karya pengudusan yang terus menerus ini baru akan mempunyai pengaruh luar biasa dan penuh dalam hidup seseorang pada saat terjadi transformasi diri yang radikal (ciptaan baru), yaitu ketika seseorang yang percaya menerima sifat baru di dalam Kristus, yang disadarinya dan diterimanya melalui iman. Mereka meninggalkan pola pikir dan kehendak lama dan belajar cara pikir baru, kehendak yang baru (Ef. 1:17-21). Misalkan, saya berhargabukan karena pencapaian kemampuan saya, tetapi karena Tuhan yang menerima saya apa adanya.

Manusia baru yang kita terima dari Kristus akan mendapat identitas yang sama dengan Kristus, yaitu kesamaan dalam kematian-Nya (Rm. 6:3, 6; Gal. 2:20; Kol. 3:1-3), penguburan-Nya (Rm. 6:4), kebangkitan-Nya (Rm. 6:5, 8, 11), hidupNya (Rm. 5:10-11), kuasa-Nya (Ef. 1:1920), warisan-Nya (Rm. 8:16-17; Ef. 1:1112). Artinya hidup lama kita sudah kita tinggalkan dan sekarang kita terus menerus belajar disem purnakan dalam sikap, keputusan, dan dalam meresponi tantangan hidup sama seperti Kristus.

Contoh dalam Alkitab mengenai identitas dalam Kristus adalah Paulus. Ia men- jelaskan dalam 1 Timotius 1:15 bahwa dirinya adalah orang yang paling berdosa. Namun, pernyataan ini dibuat jelas dalam konteks (ayat 12-16) yang menunjukkan keadaannya sebelum ia diselamatkan. Dia membuat pernyataan yang serupa tentang kejatuhan harga dirinya dalam 1 Korintus 15:9, tetapi pada ayat berikutnya ia mengungkapkan, "Tetapi karena kasih karunia Allah aku adalah sebagaimana aku ada sekarang, dan kasih karunia yang dianugerahkan-Nya kepadaku tidak siasia." (ayat 10). Semua yang dibutuhkan untuk kehidupan yang kudus sudah kita miliki melalui kuasa Tuhan yang kita warisi dari Kristus yang hidup di dalam kita (2Ptr. 1:3; Gal. 2:20; Rm. 8:37).

Selain Paulus, ada beberapa tokoh anak muda yang menunjukkan dirinya memiliki identitas dalam Kristus. Yusuf, seorang Yahudi terbuang dari negerinya, sempat menjadi budak bahkan narapidana dalam penjara Mesir, lalu menjadi penguasa tinggi. Lepas dari berbagai situasi apapun, Yusuf tetap mengingat siapa dirinya di hadapan Tuhan. Waktu ia dipertemukan kembali dengan saudara-saudaranya di Mesir, Yusuf tetap mampu melihat siapa dirinya di hadapan Tuhan, percaya dia ada dalam panggilan Tuhan menolong bangsanya yang mengalami kekeringan, ia tidak menyimpan dendam pada kakak-kakaknya.

Contoh lain adalah Daniel. Ia yang menjadi tawanan Babel, tetap menjaga identitas dalam Tuhan dengan menolak sajian makanan yang tidak berkenan pada Tuhan, taat dalam ibadah meski diancam hukuman, namun bekerja sepenuh hati untuk kebaikan Babel dan berdampak

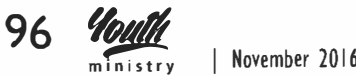


kemuliaan Tuhan dinyatakan selama ia bekerja di sana.

Kesimpulannya, identitas dan tujuan orang percaya adalah di dalam Kristus. Dia menjadi pelaku firman Tuhan karena dia telah ada di dalam firman. Dia tidak melakukannya supaya ia menjadi seperti yang ada di dalam firman. Akan tetapi, ia telah menjadi pelaku firman yang taat karena ia menjadi satu dengan firman. Di dalam Alkitab orang-orang ini disebut sebagai "saudara", "anak", "anak Allah", "anak terang", "terang dalam Allah", "orang-orang kudus", atau juga disebut diadopsi jadi anak Allah (Gal. 4:4-7). Tidak pernah Alkitab menyebut orangyang percaya sebagai "pendosa", bahkan juga tidak sebagai "pendosa yang diselamatkan oleh anugerah". Mengapa demikian? Apakah orang yang percaya tidak lagi berdosa? Tentu saja orang yang percaya masih bisa melakukan dosa. Sebutan-sebutan untuk orang percaya yang diberikan oleh Alkitab tersebut adalah sesuai dengan identitas kita yang baru di dalam Kristus. Mereka telah mati terhadap dosa dan kini hidup di dalam Kristus. Kegagalan (kejatuhan dalam dosa) orang Kristen yang sejati tidak akan mengubah atau menghentikan karya penebusan Kristus. Tetapi hal ini tidak berarti membenarkan orang Kristen yang gagal dan jatuh dalam dosa. Penebusan Kristus memberikan kuasa kepada orang Kristen sejati karena Kristus yang tinggal di dalam hati kita dan Dia tidak akan berubah. Jika seorang Kristen sejati menerima identitasnya sebagai pendosa maka identitas utamanya adalah dosa itu sendiri. Hal ini sangat bertentangan dengan apa yang telah dikatakan dalam Al- kitab, karena orang yang percaya telah dibenarkan oleh iman.

Kuasa dosa telah dipatahkan; manusia kini dapat memilih apa yang benar karena kuasa Roh Kudus dan kebenaran telah membebaskan manusia dari kuasa dosa (Yoh.8:31, 32). Orang percaya betul-betul bebas ketika melalui iman ia memilih untuk "menjadi" seperti apa yang ada dalam kenyataan, yaitu bahwa ia sudah "ada" di dalam Kristus.

Selain itu seseorang yang memiliki identitas dalam Kristus, seharusnya juga mempunyai keyakinan baru (rasa aman, meski dalam kesesakan) (Ef. 1:22). Dia memahami bahwa dia tidak ditinggalkan meski susah. Kalaupun susah, bukan berarti Tuhan buang atau saya gagal. Dia menyadari panggilan sisa hidupnya adalah menjadi duta Kristus bagi dunia lewat peperangan sepanjang kehidupannya (Ef. 4-6), dan dia hidup untuk menceritakan siapa Tuhan itu bagi sekitar.

\section{Melayani Kaum Muda dengan Meng- gabungkan Pendekatan Psikologi dan Alkitab}

\section{Aplikasi dalam Pelayanan Secara Umum}

Injil adalah tujuan paling penting dalam pelayanan untuk menjangkau orang. 0rang yang dipengaruhi oleh budaya menghasilkan identitas yang tidak sehat di dalamnya. Satu-satunya dasar yang kuat dan sehat ditemukan dalam Kristus dan hanya mereka yang memiliki hati yang baru, dan telah bertobat dari dosa-dosa mereka dapat memiliki identitas di dalam Kristus. 


\section{Satu-satunya dasar yang kuat dan sehat ditemukan dalam Kristus dan hanya mereka yang memiliki hati yang baru, dan telah bertobat dari dosa-dosa mereka dapat memiliki identitas di dalam Kristus.}

Identitas ini sesuai dengan penelitian sebelumnya di atas bahwa budaya menciptakan identitas tidak sehat pada orang. Identitas dalam Kristus dihasilkan oleh orang yang sudah mendapat keselamatan dan orang-orang ini, perlu mengingatkan diri atas identitas ini. Cara terbaik adalah untuk memberitakan identitas yang sesungguhnya dan menawarkan pemuridan atau bimbingan kepada individu karena kebanyakan orang belajar dari hubungan yang mereka miliki dan karena Allah telah memerintahkan untuk pergi dan memuridkan (Mat. 28:18-20). ${ }^{16}$

Selain memberitakan Injil kepada orang-orang yang belum diselamatkan, perlu ditanamkan identitas ini pada individu Kristen, yaitu kebenaran yang telah terjadi dan sudah terjadi dalam hidup mereka, kebenaran yang dalam persatuan dengan Kristus. Juga, penting untuk mengajarkan kebenaran yang Tuhan katakan tentang orang-orang dan memerangi me- dia sebagai ganti pikiran yang sudah terdistorsi dengan kebenaran. Misalnya, ketika media mengatakan seseorang harus menjadi cantik untuk dianggap layak, kita perlu perangi dengan menyatakan bahwa Allah peduli tentang siapa mereka dan menerima apa adanya. ${ }^{17}$

Dalam rangka untuk membantu membangun identitas yang positif pada individu, penting untuk menunjukkan keunikan mereka dan apa artinya memiliki Pencipta yang penuh kasih. Ini dilakukan dengan mendorong dan mendampingi mereka untuk menemukan identitas mereka, dan mengulangi identitas spiritual yang mereka miliki di dalam Kristus. ${ }^{18}$ Dalam rangka memerangi dunia materialisme yang mengelilingi masyarakat saat ini, seseorang harus mengajar orang lain bagaimana mendefinisikan kembali keberhasilan dan menunjukkan uang dan harta tidak sama keberhasilan dalam pikiran Allah. Salah satu cara untuk melakukan hal ini akan menjalani gaya hidup yang tidak materialistis dengan didorong oleh kerendahan hati. ${ }^{19}$ Salah satu yang paling penting adalah mengajarkan bahwa Allah memiliki segala sesuatu yang mereka miliki. Ini juga perlu dikaitkan dengan identitas mereka dalam Kristus yang memanggil mereka untuk tidak dikuasai oleh uang dan menjadi rendah hati sehingga Allah akan dimuliakan dengan diri mereka dan bagaimana mereka melayani Dia dan mengasihi orang lain.

16. Richard R. Dunn, Shaping the Spiritual Life of Studen : A Guide for Youth Workers, Pastors, Teachers, and Campus Ministers (Downers Grove, IL: InterVasity Press, 2001).

17. Walt Mueller, Youth Culture 101 (Grand Rapids, MI: Zondervan, 2007)

18. Tiffany Stuart, "Six Ways to Build Your Teen's Identity," https://www. focusonthefamily.com/parenting/teens/your-teensidentity/build-your-teens-identity (diakses 15 November 2011).

19. Mueller, Youth Culture 101. 


\section{Pelayanan untuk Remaja}

\section{Menciptakan Lingkungan yang Penuh Kebenaran}

Untuk remaja, salah satu cara yang membantu melindungi pikiran mereka dari klaim yang berasal dari budaya tentang siapa diri adalah menempatkan mereka dalam lingkungan Kristen setelah pulang sekolah. Peran keluarga dan komunitas Kristen penting untuk menciptakan lingkungan belajar yang positif bagi siapa mereka di dalam Kristus. Jalan untuk melakukan hal ini adalah membantu mereka dalam membangun kelompok komunitas, menciptakan pengalaman di mana mereka dapat hidup iman mereka, menyediakan waktu yang bermakna dengan mereka berinteraksi dengan orang dewasa, memberikan kesempatan bagi mereka untuk memberikan kontribusi, dan terakhir untuk berkomunikasi soal moral dengan batas dan menciptakan ekspektasi perilaku bagi mereka untuk hidup seperti yang ditunjukkan dalam Alkitab. ${ }^{20}$

\section{Membantu Remaja Melalui Fase Mora- torium}

Cara lain untuk membangun identitas di dalam Kristus adalah membantu remaja melalui tahap perkembangan identitas mereka di tahap moratorium. Cara terbaik untuk menangani situasi remaja berjuang dengan krisis identitas mereka adalah memberi ruang dan memahami bahwa itu adalah proses seorang remaja yang membutuhkan jawaban atas keraguan dan juga perlu diingatkan siapa mereka di dalam Kristus secara terus menerus.

\section{Menjadi Panutan atau Model}

Cara lain adalah dengan meminta mereka menemukan apa yang begitu penting dalam hidup mereka, sehingga mereka tidak bisa hidup tanpa itu, atau cara lain adalah dengan melihat melalui lensa budaya untuk melihat apa yang sedang diajarkan budaya untuk remaja. Lalu minta mereka melakukan pengamatan untuk menunjukkan kebohongan dalam budaya, memberitahu mereka untuk kembali kepada Alkitab, tetapi ini perlu dijalani melalui relasi yang membantu remaja, karena remaja akan belajar lewat model mereka. Selain itu penting untuk membangun hubungan dengan remaja dan menjadi duta Kristus, sebagai refleksi dari Bapa Surgawi untuk menunjukkan pada remaja apa artinya memiliki hubungan dengan Kristus dan hidup di dalam Kristus.

Together, we can ground the next generation in deep, solid, biblical convictions that will enable them to live as "children of God without fault in a crooked and depraved generation, in which [they] shine like stars in the universe" (Philippians 2:15). 


\section{Daftar Pustaka}

\section{Buku:}

Marcia, James E. "Identity in Adolescent." Dalam Handbook of Adolescent Psychology, ed. Joseph Adelson. New York: John Wiley \& Sons, 1980.

Santrock, John W. Essential of Life-Span Development. New York, NY: McGraw-Hill Education, 2007.

McDowell, Josh dan Bob Hostetler. Right from Wrong. Nashville: Word Publishing, 1995.

Vukich, Lee dan Steve Vandegriff. Timeless Youth Ministry: A Handbook for Successfully Reaching Today Youth. Chicago IL: Moody Publisher, 2002.

Driscoll, Mark. Who Do You Think You Are?: Finding Your True Identity in Christ. Nashville, Tennessee: Thomas Nelson, 2013.

Dunn, Richard R. Shaping the Spiritual Life of Students: A Guide for Youth Workers, Pastors, Teachers, and Campus Ministers. Downers Grove, IL: InterVasity Press, 2001.

Mueller, Walt. Youth Culture 101. Grand Rapids, MI: Zondervan, 2007.

\section{Internet:}

"80 Persen Remaja Indonesia Kecanduan Internet." http://www.wowkeren.com/ berita/tampil/00046680.html (diakses 15 November 2011).

Nanlohy, Alex. "Remaja Kristen di Tengah Kungkungan Krisis Zaman." https://www. kompasiana.com/alexnanlohy/55202b75a333110744b65bdc/remaja-kristendi-tengah-kungkungan-krisis-zaman (diakses 31 Oktober 2015).

http://repository.maranatha.edu/8077/3/0430108_Chapter1.pdf (diakses 31 Oktober 2015). 
"Identity Crisis Test." http://www.wholeperson-counseling.org/ndoc/id-test.html (diakses 31 Oktober 2015).

Pederson, Mathew S. "Establish a Solid Foundation through an Identity in Christ." Tesis, Liberty University, 2015. https://digitalcommons.liberty.edu/honors/510/ (diakses 31 Oktober 2015).

Munir, Misbahol. “Tiap Tahun, Remaja Seks Pra Nikah Meningkat.” https://news. okezone.com/read/2010/12/04/338/400182/tiap-tahun-remaja-seks-pra-nikahmeningkat (diakses 15 November 2011).

Soni, "93 Persen Pengguna Narkoba Masuk Us ia Produktif." http://lampung. tribunnews.com/2012/05/05/93-persen-pengguna-narkoba-masuk-usia-produktif (diakses 15 November 2011).

Stuart, Tiffany. "Six Ways to Build Your Teen's Identity." https://www.focusonthefamily. $\mathrm{com} /$ parenting/teens/your-teens-identity/build-your-teens-identity (diakses 15 November 2011).

Mueller, Walt. "Identity, World and Word." https://cpyu.org/resource/identity-worldand-word/2009/ (diakses 15 November 2011). 